\title{
咬合終末期における顎運動パターンとその咬合状態
}

\author{
長谷 誠, 相馬邦道 \\ 東京医科歯科大学歯学部歯科矯正学第 1 講座（主任：相馬邦道教授） \\ 〔受付: 平成 8 年10月 1 日]
}

\section{The Relationship between Occlusal Condition and Patterns of Masticatory Movement during the Final Stage of Occlusion}

\author{
Makoto Hase, Kunimichi Soma \\ The First Department of Orthodontics, Faculty of Dentistry, Tokyo Medical and Dental University \\ (Director: Prof. Kunimichi Soma) \\ [Recieved: October 1, 1996.]
}

Key words: masticatory efficiency, masticatory movement, non-linear dynamic analysis, final stage of occlusion, occlusal condition

\begin{abstract}
The purpose of this study was to investigate the relationship between the occlusal condition and the patterns of masticatory movement during the final stage of occlusion by means of evaluating the efficiency in food breakdown.

The methods and the results were as follows:

1. Two subjects with Angle's Class II and one subject with normal occlusion were selected. On the basis of the occlusal condition and the relationship of the maxillary and mandibular teeth, the mastication, and the occlusal force of the subjects, the efficiency in food breakdown was evaluated by finite element non-linear dynamic analysis. The results showed that there was only little characteristic difference in the timing of the masticatory efficiency among the subjects.
\end{abstract}

2 . In each subject, according to the subjects' records of mastication, the movement direction of their mandibular first molars during the final stage of occlusion was observed. The results showed that the amount of the movement of mandibular first molars in the subjects with Angle's Class II, compared with that in the subject with normal occlusion, was large in antero-posterior direction.

3 . During the final stage of occlusion, the movement direction of mandibular first molars in the subjects with Angle's Class II was replaced by that of the subject with normal occlusion, and the efficiency in food breakdown was evaluated. The results showed the conspicuous declination in the timing of the masticatory efficiency.

The obtained results imply that the masticatory movement direction compensates for the difference in the position and the occlusal surface morphology of the maxillary and mandibular teeth; consequently, the efficiency in food breakdown is made to be higher.

連絡先： $=113$ 東京都文京区湯島 $1-5-45$ 
抄録 本研究の目的は, 咬合状態と咬合終末期における顎運動パターンとの関連性を, 食塊の破壊粉砕効 率を基に検討することである.

検討の方法および結果は，以下のとおりである.

1. 被験者として，アングル II 級症例 2 名と正常咬合症例 1 名を選択した。これらの上下顎歯の咬合面形 状と位置関係，および咀嚼運動と咬合力を用いて，有限要素法非線形動解析により食塊の破壊粉碎効 率を求めた．その結果, 症例間に著明な経時的咀嚼効率の差異は認められなかった。

2. 顎運動記録より，それぞれの症例について，咬合終末期の下顎第一大鼠歯の運動方向を観察した。 そ の結果，アングル II 級症例の下顎第一大臼歯の運動方向は, 正常咬合症例のそれに比較して前後成分 が大きかった。

3. アングル I 級症例について，咬合終末期における下顎第一大臼歯の運動方向を，正常咬合症例のそれ と入れ換えて食塊の破壊粉砕効率を求めた，その結果, 経時的咀緭効率は著しく低下することが認め られた.

このことにより, 咀嚼運動方向は, 上下顎歯の位置の差異を補い, 食塊の破壊粉砕効率を高めている可 能性があることが示唆された.

\section{I. 緒 言}

咬合の主たる機能は咀嚼すなわち食塊の破壊粉砕であ ると考えられる，その破壊粉砕の効率を高める形態的因 子として, 歯の形態および上下顎歯の位置関係等, 機能 的因子として，顎運動および咬合力等が挙げられる。さ らに,これら両因子には密接な関係があると言われてい る。

歯科矯正の分野では, 形態的, 機能的両因子の関係を 検討した幾つかの報告が散見される. 石川ら ${ }^{11}$ は，上下 顎歯の位置関係，すなわち咬合状態と顎運動パターンの 様相を，大道 ${ }^{21}$ は，正常咬合者と上顎前突者に対し，そ れらの顎運動および筋電図所見を報告している。また,

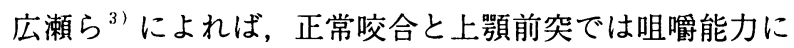
差はないとの報告もある.

このように, 形態と機能の関係には多くの関心が寄せ られているものの，それらの相互関連性ついては不明の ままである。

従来より，著者らは，咬合終末期に扔ける上下顎歯間 の食塊の応力分布状態 ${ }^{4}{ }^{51}$ 加, 不正咬合者の食塊の破 壊粉砕効率を検討してきている.

そこで著者らは, 今回, 上記の形態と機能の課題の検 討の一つとして, 歯科矯正学の立場から近遠心的な不正 咬合である アングル II 級 1 類症例をとりあげ，正常咬 合症例との食塊の破壊粉碎効率の比較を行った。その結 果, 両者のそれぞれの咬合状態と顎運動の運動方向との 間に関連性が示唆されたので報告する.

\section{II. 研究方法}

\section{1. 資料}

被験者には顎口腔系に特に異常を有しないものを選択 した. 今回は 1 歯対 2 歯の対咬関係を持つ正常咬合 1 症 例（normal）と， 1 歯対 1 歯の対咬関係を持つ半咬頭了 ングル II 級不正咬合 2 症例（Angle II a, Angle II b ）を資 料として用いた。

\section{2. 食塊の破壊粉砕効率の評価方法}

今回用いた食塊の破壊粉碎効率の評価方法を，一般的 な有限要素解析の手順に従って述べる.

上下顎歯の形状の測定には久野らの方法 ${ }^{6)} に$ 準じ, 全 顎咬合面の形状および咬頭嵌合位における上下顎相互位 置関係を測定した。これらの形状データょり上下顎右側 第一大臼歯部データを抽出し検討に供した.

咀嚼時の顎運動の測定には， 6 自由度顎運動記録装置 （松風社製 MM-JI-E）を用いて，グミ咀嚼における運動 データを記録した（図 1)。これらょり下顎右側第一大 臼歯の咀嚼経路デー夕を出力した。

咬合終末期における上下顎右側第一大臼歯ならびにそ の間に介在する食塊を解析対象とするため，モデルにお いては，咀噮運動中の上下顎歯間関係を反映させた。す なわち，上述の下顎第一大臼歯咀嚼運動データを用いて， 咬頭嵌合位における上下顎右側第一大臼歯咬合面デー夕 のうち下顎歯部デー夕を, その位置から咀嚼経路上に遡 って，コンピュータ上で移動させた，その位置において， 上下顎右側第一大臼歯およびそこに介在する食塊を想定 し, 三次元有限要素モデルを作製した（節点数約 2500 , 要素数約 1500$)$. 


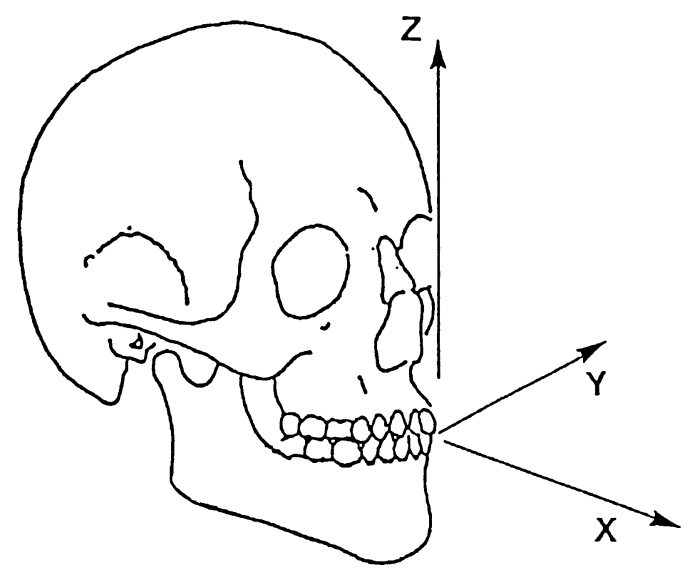

図 1 座標軸の設定

Fig. 1 Established coordinate axes

食塊モデルの物性については,グミキャンディーを想 定した。

上記の有限要素モデルに対し, 拘束条件および荷重条 件を設定した。拘束条件として, 咀嚼時を想定して上顎 第一大白歯部モデルの最上部の全節点に対し, 垂直的か つ水平的な完全拘束を行った. 荷重条件として, 下顎歯 モデルの最下部の全節点に対し荷重を与え ${ }^{7)}$, 荷重の方 向は咀嚼経路上を咬合終末位へ至る方向へ与えた。

以上の条件の下で, 有限要素法非線形動解析（米国 Lawrence Livermore National Laboratory 製 DYNA3D）に より, 経時的咀嚼効率を算出した。 また,ここでいう経 時的咀嚼効率とは, 食塊がある一定時間に破壊粉砕され る量の割合と定義した。すなわち, 食塊の全要素に対し て破壊に達した要素数の割合を, その時刻の破壊効率と

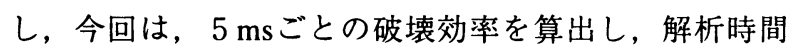
は20msとした。

\section{3. 検討方法}

まず，1）上下顎右側第一大臼歯間における食塊の経 時的咀嚼効率を, 上述の評価方法に従って算出し, 正常 咬合とアングル II 級症例とを比較した。ついで，2）荷 重条件である顎運動方向のみに着目し, 同様の比較を行 った.さらに，3）咬合状態と顎運動方向との関連性を 明らかにするため, 顎運動方向を入れ換えた場合の食塊 の経時的咀嚼効率を, 仮想の解析（II－Ｉとする）によ って算出し, 同様の比較を行った.
表 1 全食塊要素に対する破壊された食塊の 割合

Table 1 Ratio of the brokendown food elements to the overall food elements

\begin{tabular}{l|c|c|c|c}
\hline \hline 時間 (msec.) & 5 & 10 & 15 & 20 \\
\hline normal (\%) & 18 & 25 & 65 & 100 \\
Angle II a (\%) & 22 & 33 & 50 & 95 \\
Angle II b (\%) & 20 & 36 & 48 & 91 \\
\hline
\end{tabular}

III. 結

\section{1. 有限要素法による解析から}

解析結果を表 1 に示す．半咬頭アングル II 級症例の経 時的咀嚼効率は, 正常咬合症例のそれと比べ顕著な差異 は認めなかった。

\section{2. 顎運動の観察から}

記録された咀嚼運動データのうち下顎右側第一大曰歯 のデータから, その各ストロークにおける, 咬頭嵌合位 より $1 \mathrm{~mm}$ 遡った咀嚼経路上における運動方向（入射方 向）を抽出した。この点の速度成分を，前後ならびに左 右の成分に分割し，咀嚼運動がどのような方向にあるの かを観察した。

その結果, 半咬頭アングル II 級症例の咀嚼運動方向は, 正常咬合症例のそれに比して, 前後的成分の割合が大き かった（図 2 ).

\section{3. 仮想の解析から}

半咬頭アングル II 級症例に正常咬合症例の咬合終末期 の入射方向を解析条件として代入し, 経時的咀嚼効率を 算出した。

解析結果を表 2 に示す．入射方向を代えた結果，半咬 頭アングル II 級症例の経時的咀嚼効率は低下した.

\section{IV. 考察}

\section{1. 有限要素解析の結果について}

半咬頭アングル II 級は上下顎歯が 1 歯対 1 歯の咬合状 態であり, 咬合の緊密さから推察するところ, 正常咬合 の 1 歯対 2 歯のそれと比べ, 咀嚼効率が劣ると考えられ る。また, 久野ら ${ }^{8)}$ は, 形態のみを対象としたモデル実 験から，1歯対 1 歯の咬合では 1 歯対 2 歯のそれと比べ, 食塊に生じる破壊エネルギーが小さいと報告している.

しかしながら, 今回の解析では症例間に顕著な相違は 


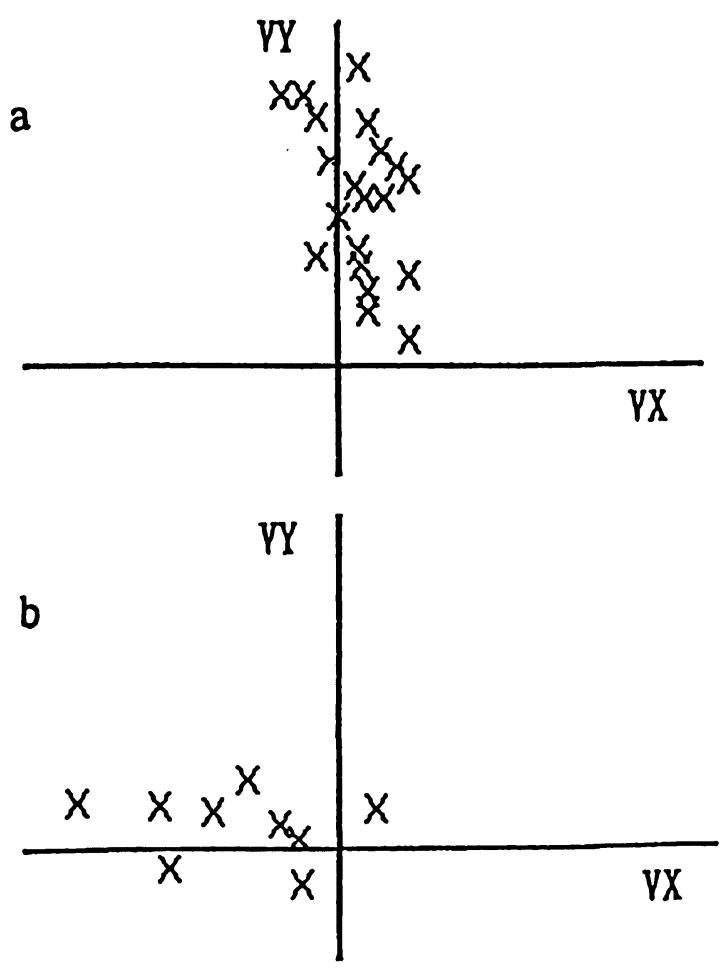

図2 下顎右側第一大臼歯の入射方向

Fig. 2 Direction of movements of the mandibular right first molar a: normal; b: Angle II

認められなかった。このことから，咀緭効率は，咬頭嵌 合位おける上下顎歯の接触状態だけでなく，顎運動等の 他の要素にも大きく左右されるものと考えられる.

\section{2. 咬合終末期の咀嚼運動方向について}

咀嚼運動路についての研究は古くから行われ，前頭面 に関しては, 咀嚼運動の閉口路終末期と側方運動路はほ ほ一致すると報告されている ${ }^{9 !}$. また，矢状面に関して は，咬合平面と咀嚼閉口路はほほ直角に近いと報告され ている ${ }^{10)}$.このようにいわゆる正常咬合において，前後 的成分よりは側方成分の大きな咀嚼運動が統計的に観察 されている．今回の不正咬合症例の観察では前述の上う な正常咬合の顎運動パターンを示しておらず，前後成分 の大きい運動を示していた.

このことから，その咬合状態に応じた枵運動が, 前項 で観察されたような食塊の破壊粉砕効率を修飾している ことが想像される。
表 2 Angle II aに対する II - I の各時刻で

の割合

Table 2 Time ratio of II - I to Angle II a.

\begin{tabular}{c|c|c|c|c}
\hline \hline 時間 (msec.) & 5 & 10 & 15 & 20 \\
\hline II - I (\%) & 45.5 & 41.7 & 62.0 & 42.1 \\
\hline
\end{tabular}

\section{V. 結}

アングル II 級 1 類症例に関して咀嚼運動方向は，上下 顎歯の位置の変異を補い, 食塊の破壊粉砕効率を高めて いる可能性があることが示唆された。

\section{文献}

1）石川晴夫, 中村俊弘，新井孝ほか：不正咬合者にお ける咀嚼運動の機能的分析一I 級不正咬合者の咀呬 運動経路について一，日矯歯誌，48，108，1989

2 ）大道貞祥：混合歯列期における正常咬合者と上顎前 突者の顎の運動学的ならびに筋電図学的研究，岐歯 学, 16, 147-163, 1989

3 ）広瀬寿秀, 中山二博, 相星順子ほか：不正咬合者の 咀嚼能率と矯正治療による変化, 日矯歯誌, 51 , 302-307, 1992

4）相馬邦道：咬合面形状の定量化一咬合応力解析への アプローチー, 歯医学誌, 13, 76-81, 1994

5 ）石田哲也, 相馬邦道 : 咬合終末期における上下顎第 一大臼歯間の応力解析, 日矯歯誌, 52, 161-172, 1993

6 ）久野昌隆, 黒木健広, 相馬邦道: 咬合状態の評価法 としての上下顎歯間距離一咬合終末位およびその近 傍において一，日矯歯誌，52，73-78，1993

7 ）森川昭彦：下顎第一大臼歯における機能時の咬合力 に関する研究，口病誌，61，250-274，1994

8 ）久野昌隆, 石田哲也, 相馬邦道：食塊モデルにかか る咬合エネルギー 第 2 報, 第 3 回額顔面バイオメ カニクス学会講演論文集, 48-50, 1994

9 ) Gibbs, C.H., Lundeen, H.C., Manhan, P.E., et al.: Chewing movements inrelation to border movements at the first molar, J Prosthet Dent, 46: 308-322, 1981

10）小川隆広, 古谷野潔, 住吉圭太ほか：咬合平面と咀 緭閉口路との垂直的な関係，顎機能誌，2，129-133， 1996 